Original Research

\title{
Life Cycle Assessment for Enhanced Efficiency of Small Power Plants by Reducing Air Input Temperature
}

\author{
Phairat Usubharatana, Harnpon Phungrassami*
}

Excellence Centre of Eco-Energy (ECEE), Department of Chemical Engineering, Faculty of Engineering, Thammasat University, Pathumthani, Thailand

Received: 9 August 2017

Accepted: 9 October 2017

\begin{abstract}
This research aimed to study the relevant work relating to environmental evaluation associated with global warming, acidification, eutrophication, and human toxicity from the $120 \mathrm{MW}$ combined-cycle cogeneration power plant through use of a life cycle assessment. The functional units of study were one $\mathrm{kWh}$ of electricity and one ton of steam production. The system boundary of this study comprised unit processes related to a gas turbine power plant and thermal power plant using natural gas. Input data including natural gas and demineralized water in the gas turbine process, while oxygen scavenger chemicals such as neutralizing amine and phosphate were included in the steam turbine process. We found that global warming potential and acidification potential came primarily from gas combustion during the production process, while transportation posted a minor contribution, while eutrophication potential and human toxicity caused by $\mathrm{NaOCl}$ was $10 \%$. The feasible ways to reduce environmental impacts included cooling down the air temperature prior to being fed to the compressor using the evaporative method and the fogging method. The results found that the fogging method was proven to reduce global warming potential more significantly than the other method. On the other hand, the evaporative method was more effective in terms of acidification, eutrophication, and human toxicity reduction.
\end{abstract}

Keywords: cogeneration, evaporative method, fogging method, life cycle assessment, power plant

\section{Introduction}

According to a previous report, the largest sources of GHG emissions came from fossil fuel electricity generation [1]. The 2015 United Nations Climate

*e-mail: pharnpon@engr.tu.ac.th
Change Conference, or COP21, had the primary objective of negotiating for an agreement to keep the rise in global temperature well below $2^{\circ} \mathrm{C}$ above preindustrial revolution levels. This binding agreement was intended be implemented and enforceable by all member countries by 2020 [2]. In Thailand, a 20\% reduction in GHG emissions is planned by 2030. One possible plan involves cutting down fossil fuel consumption and turning to other alternative, more eco-friendly energy 
resources instead. According to the Thailand Power Development Plan for the period between 2015 and 2036 [3], the Energy Efficiency Development Plan [4] and the Alternative Energy Development Plan [5], Energy Policy and Planning Office [3], and the Ministry of Energy has set paths to achieve such an objective by implementing the following:

1) Energy security: develop electricity supply to adequately meet demand and promote diversification of fuel types in order to avoid overwhelming dependency on any single source.

2) Economy: consideration of the cost-effectiveness and efficient use of electricity.

3) Ecology: minimize the impact on the environment and community, focusing on the goal to reducing GHG emissions per one electricity unit generated.

Thailand's economic growth from 2014 to 2036 is anticipated to average $3.94 \%$ annually [3]. As a result, the net demand for electricity should increase by $2.67 \%$ per year [3]. To serve the ever-increasing electricity demand in the country, new power plants have to be constructed. However, such a plan cannot be executed immediately. Thus, the focus should be on increasing efficiency in existing power plants in order to improve productivity. The current net productivity of all power plants nationwide is $37,612 \mathrm{MW}$, as shown in Table 1. Based on Table 1, most of the power plants in the country, accounting for $56.2 \%$, are cogeneration power plants, while $22.5 \%$ are renewable energy power plants. The goal to reduce $\mathrm{GHG}$ emissions associated with energy involves promotion for the use of renewable energy in accordance with the Alternative Energy Development Plan for 2014-2023 [5] and taking measures to ensure the efficiency of energy consumption.

From the aforementioned statements, energy demand within the country is on the rise. As such, power plant productivity needs to be improved with less GHG emissions per set target. One of the considerations is to lower the heat rate while generating electricity. The most widely used method consists of cooling down the air temperature prior to it being supplied to the air compressor. Doing this helps increase the density of air inflow into the plant, thereby increasing power generation [6]. This method is applied to the evaporative cooling system, fogging system, and chilled

Table 1. Proportionality of the Thai power system.

\begin{tabular}{|c|c|c|}
\hline Type & Capacity (MW) & Percent \\
\hline Cogeneration power plant & 21,145 & 56.2 \\
\hline Thermal power plant & 7,538 & 20.0 \\
\hline Renewable power plant & 8,476 & 22.5 \\
\hline Gas turbine diesel engine & 153 & 0.5 \\
\hline Malaysia-Thailand pipeline & 300 & 0.8 \\
\hline
\end{tabular}

Source: Thailand Power Development Plan 2015-2036 [3] water system, etc. From a case study, a fogging system was used in a $138.7 \mathrm{MW}$ combined-cycle power plant and its efficiency increased by $5.73 \%$ [7]. In addition, productivity was increased by $11.3 \%$ when a vapour absorption chiller was used in a gas turbine power plant to cool the air temperature before compressor intake for a 16.6 MW gas turbine [8]. During electricity generation in the summer, cooling down the air temperature to $4^{\circ} \mathrm{C}$ into a combustion turbine and $27 \%$ efficiency increase could be observed [9].

Despite these facts, increasing efficiency definitely poses certain effects on the environment in other aspects. Hence, life cycle assessment (LCA) is one of the most effective and frequently used tools employed to quantify such effects caused by power plants that utilize diverse fuel resources [10-11]. Some researchers, including Chevalier and Meunier [12], have studied the environmental assessment of biogas co- or trigeneration units using LCA methodology. Gonzalez et al. [13] studied thermo-economics to the allocation of environmental loads in the LCA of cogeneration plants. Moreover, Mahlia and Chan [14] studied life cycle cost analysis for a fuel cell-based cogeneration system in China, while Li et al. [15] studied life cycle energy use and GHG emissions of cogeneration technology in China. Several researchers have looked at LCA of cogeneration power plants using bagasse, such as Guerra et al. [16], who studied the LCA of electricity cogeneration in sugarcane, and Ramjeawon [17], Gil et al. [18], Mashoko et al. [19], and Silva et al. [20].

To serve the ever-increasing energy demand in the country with an aim to reduce environmental effects, this study focused on the environmental impact caused by power plant productivity improvement from combined cycle power plants using LCA. The focus group in this study was of small power producers (SPP) ranging from 100-150 MW power plants. This is because SPP power plants collectively generated 8,500 MW in 2015, which accounted for $23 \%$ of total electricity generation capacity in Thailand [21].

\section{Material and Methods}

LCA is an internationally standardized methodology applied according to ISO 14040 series [22]. LCA is a systematic approach to evaluate the environmental impact of products and services throughout all life cycle stages [23], which refer to activities during a product's lifetime starting from raw material acquisition, its manufacture, use, and maintenance to its final disposal [24]. It is one of the most developed and widely used environmental assessment tools available to compare alternative technologies [25] or products with the same functional unit. In general, two approaches are used, including process chain analysis and inputoutput analysis [26]. Input-output analysis is a topdown economic technique that describes the complex interdependencies of industries to trace resource 
requirements and pollutant releases throughout an entire economy [27]. Conversely, process chain analysis is a bottom-up approach. In this study, the process chain analysis approach was chosen because it offered more precise results [28]. According to ISO 14040 [22] and ISO 14044 [29], LCA consists of four steps, including goal and scope definition, life cycle inventory, life cycle impact assessment, and interpretation.

\section{Goal and Scope Definition}

The first step of LCA methodology is goal and scope definition, which provides a description of the product system, including functional unit and system boundaries [30]. The principal goals of this LCA study were:

1) To calculate the environmental impact of electricity and steam generation from a combined-cycle cogeneration power plant of SPP between 2013 and 2015.

2) To identify the hot-spot contributors to the environment.

3) To investigate the environmental impact of different improvements to power plant efficiency.

We applied evaporative and fogging methods in order to improve the efficiency of a power plant by reducing the temperature of air input to the compressor.

In this analysis, the functional unit needed to be determined and was considered one of the most essential parts of scope definition. The functional unit expresses the function of the products and offers a way to compare the overall environmental performance of different product systems. The products of the power plants in this study were electricity and steam. Therefore, the functional unit of the investigation was selected as one $\mathrm{kWh}$ of electricity generation and one ton of steam (heat content of steam was defined at 14 bars $200^{\circ} \mathrm{C}$ equivalent to enthalpy $2,803 \mathrm{MJ} /$ ton steam), which was aligned to the study by Atilgan and Azapagic [31], Clarens et al. [32], and Garcia-Gusano et al. [33], in which the functional unit was quantified at one kWh of electricity. It was also similar to the studies of Brizmohun et al. [34], Corona et al. [35], and Dzikuc and Tomaszewski [36], for which the functional unit was also one MWh.

The geographical boundary of the study was set for electricity and steam generation in the central part of Thailand, with net generation capacity of approximately $120 \mathrm{MW}-45 \%$ of which was sold to the Electricity Generating Authority of Thailand. The remainder went to customers in industrial zones. The system boundary of this study comprised unit processes related to a gas turbine power plant and thermal power plant using natural gas imported from Myanmar in 2013-2014 and produced in the Gulf of Thailand in 2015. The heat generated from combustion propelled a gas turbine equipped with a shaft coupled to a power generator. As a result, electricity was generated. Subsequently, the massive hot gas released from the turbine was supplied to the heat recovery steam generator (HRSG) in order to generate steam to drive the steam turbine, which was also fitted with a shaft coupled to another power generator. Consequently, the entire system could generate electricity equivalent to a power generator from a gas turbine and steam turbine combined (Fig. 1). Furthermore, there were support machines

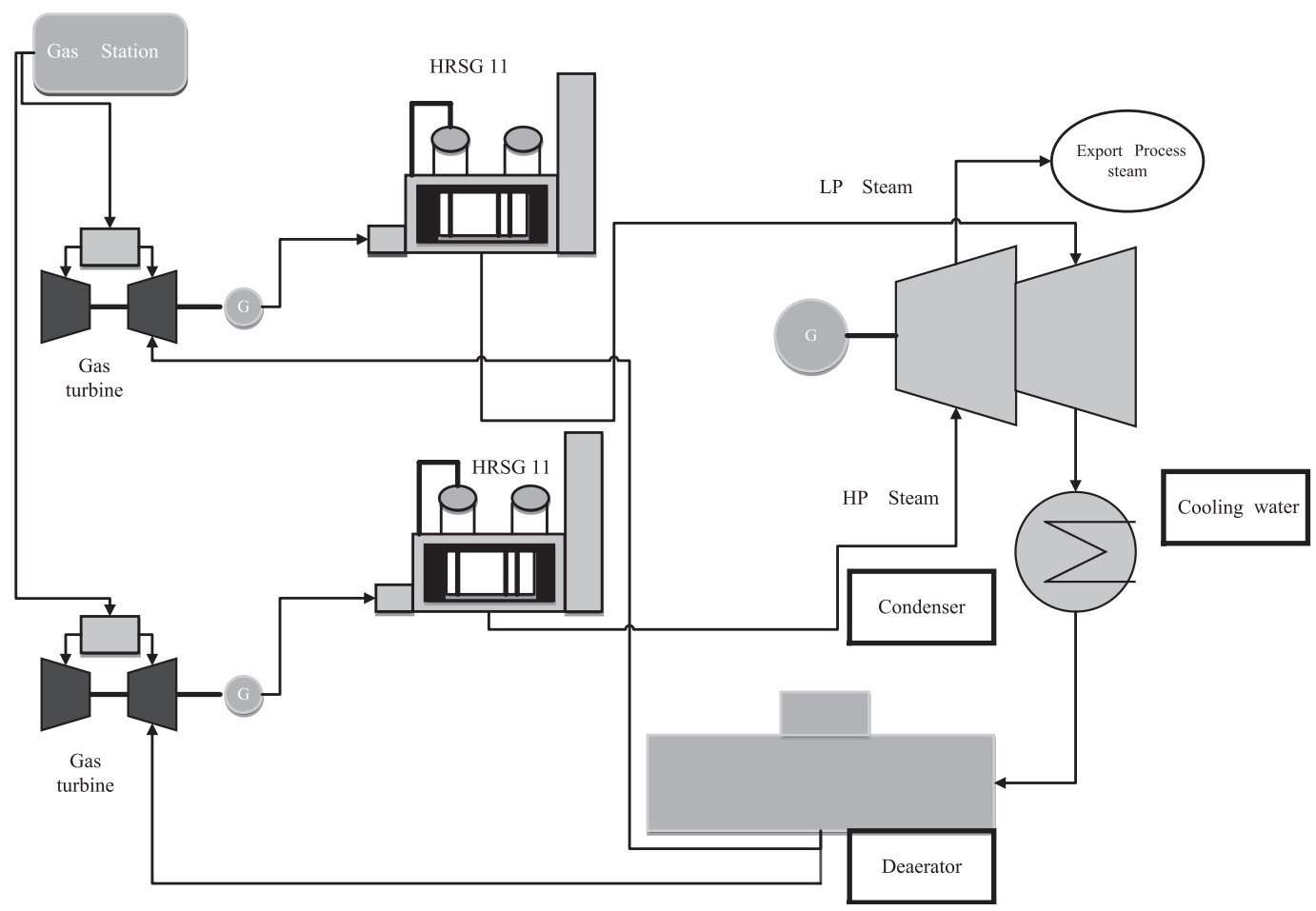

Fig. 1. Cogeneration combined power plant. 
Table 2. Calculation of allocation factors.

\begin{tabular}{|c|c|c|}
\hline Year & $\begin{array}{c}\text { Allocation factor } \\
\text { for electricity }\end{array}$ & $\begin{array}{c}\text { Allocation factor } \\
\text { for steam }\end{array}$ \\
\hline 2013 & 95.07 & 4.93 \\
\hline 2014 & 91.56 & 8.44 \\
\hline 2015 & 91.30 & 8.70 \\
\hline
\end{tabular}

such as a condenser, cooling tower, chiller, and water treatment plant. The system boundary was set as cradle to gate, in other words, from material acquisition, materials transportation to the power plant, including electricity and steam generation. The infrastructure, equipment, and dismantling of buildings or equipment were excluded from the scope of this study.

Environmental loads in the focused processes yielding several useful products or co-products were allocated [13]. The products of a cogeneration power plant referred to in this study were electricity and steam, so it was necessary to allocate environmental loads to both products. Thai was accomplished by primarily converting electricity and steam power in the same MJ unit $(1 \mathrm{kWh}=3.6 \mathrm{MJ})$. The allocation ratio is shown in Table 2. Variance was caused by the fluctuation of product yields (electricity and steam) during each year.

\section{Life Cycle Inventory}

The production process started when the natural gas was delivered through the pipeline. During 20132014 the gas was initially imported from Myanmar. However, by 2015 it could be produced in the Gulf of Thailand as well. The gas pressure was subsequently increased to 52 bars through a gas compressor and ignited in the combustion chamber of a gas turbine. The hot gas acquired from this combustion was used to drive the turbine connected to an electricity generator, yielding 2 sets of $47 \mathrm{MW}$ electricity generation. The used gas was then sent to heat water in the heat recovery steam generator to get steam to move a steam turbine coupled with another electricity generator, yielding another $23 \mathrm{MW}$ electricity power and 20 ton/h steam. The water used in the production process was supplied by an external vendor through a pipeline with a reverse osmosis filter set and resin. The production capacity was $35 \mathrm{~m}^{3} / \mathrm{h}$ of demineralized water. The water used in the cooling tower, however, was not treated by a reverse osmosis filter. Thus, the wastewater was delivered elsewhere for treatment by an outside company. The production information was acquired from on-site collection, while that of material acquisition such as $\mathrm{HCl}, \mathrm{NaOH}$, or $\mathrm{H}_{2} \mathrm{SO}_{4}$ productions was obtained from a reliable database such as the Eco-Invent Database [37] and various literature. Mass and energy balances were applied to check and analyze the data. Tables 3 and 4 demonstrate the main inventory data for this study. As Table 3 shows, the amount of demineralized water used in 2013 was lower than two years later since full capacity was not achieve and most steam generated from the power plant was condensed back to the system. During 2014-2015, full capacity was reached and almost all of the steam was sent to customers, therefore not only demineralized water was increased, but chemicals used for water treatment, such as phosphate, were increased as well. In case of neutralizing amine, consumption was decreased due to the effect of power plant efficiency increasing rather than the effect of demineralized water consumption.

\section{Life Cycle Impact Assessment}

Since electricity generation is a key contributor to global emissions of greenhouse gases such as $\mathrm{NO}_{x}$ and $\mathrm{SO}_{2}$ [26], this study focused on assessing

Table 3. Main inventory data associated with delivery of $1 \mathrm{MJ}$ of electricity and steam, obtained from cogeneration.

\begin{tabular}{|c|c|c|c|c|}
\hline \multirow{2}{*}{ Environmental load } & \multirow{2}{*}{ Unit } & 2013 & 2014 & 2015 \\
\cline { 3 - 5 } \multicolumn{2}{|c|}{ Gas turbine } & $2.05 \mathrm{E}+00$ \\
\hline Natural gas & $\mathrm{MJ}$ & $2.08 \mathrm{E}+00$ & $2.05 \mathrm{E}+00$ & $1.03 \mathrm{E}-05$ \\
\hline Demineralized water & $\mathrm{m}^{3}$ & $1.62 \mathrm{E}-06$ & $6.11 \mathrm{E}-06$ & $8.61 \mathrm{E}-09$ \\
\hline Chiller & $\mathrm{m}^{3}$ & $1.80 \mathrm{E}-08$ & $8.62 \mathrm{E}-09$ & $3.81 \mathrm{E}-05$ \\
\hline \multicolumn{5}{|c|}{ HRSG and steam turbine } \\
\hline Demineralized water & & $2.78 \mathrm{E}-05$ & $3.89 \mathrm{E}-05$ & $1.14 \mathrm{E}-07$ \\
\hline Oxygen scavenger & $\mathrm{m}$ & $1.92 \mathrm{E}-07$ & $1.52 \mathrm{E}-07$ & $1.04 \mathrm{E}-07$ \\
\hline Neutralizing amine & $\mathrm{kg}$ & $1.41 \mathrm{E}-07$ & $1.05 \mathrm{E}-07$ & $9.72 \mathrm{E}-08$ \\
\hline Phosphate & $\mathrm{kg}$ & $4.95 \mathrm{E}-08$ & $1.13 \mathrm{E}-07$ & $2.70 \mathrm{E}-04$ \\
\hline Cooling water & $\mathrm{kg}$ & $3.16 \mathrm{E}-04$ & $2.67 \mathrm{E}-04$ & $9.88 \mathrm{E}-05$ \\
\hline Wastewater & $\mathrm{m}$ & $1.21 \mathrm{E}-04$ & $8.89 \mathrm{E}-05$ & \\
\hline
\end{tabular}


the environmental impact from the aspect of global warming potential $\left(\mathrm{kg} \mathrm{CO}_{2} \mathrm{eq} / \mathrm{kWh}\right.$ and $\mathrm{kg} \mathrm{CO}$ eq/ ton steam) using the IPCC2007 method [38]. However, the study of Turconi et al. [26] suggesting that global warming potential assessment was only one-sided information that could lead to oversimplification, acidification ( $\mathrm{kg} \mathrm{SO}$ eq/kWh and $\mathrm{kg} \mathrm{SO}$ eq/ton steam), eutrophication ( $\mathrm{kg} \mathrm{Peq} / \mathrm{kWh}$ and $\mathrm{kg}$ Peq/ton steam), and human toxicity $(\mathrm{kg} 1,4 \mathrm{DBeq} / \mathrm{kWh}$ and $\mathrm{kg} 1,4 \mathrm{DB}$ eq/ton steam) were also taken into account for this study. The assessment methodology, Recipe Midpoint World ( $\mathrm{H}$ perspective) was applied with SimaPro 7.3.2 software because it has been more frequently used in modern studies of electricity generation, such as that of Corona et al. [35].

\section{Interpretation}

This assessment is associated with environmental impact contribution as a result of resource exploitations and waste emissions caused by the generation process. The environmental impact of each aspect was

Table 4. Inventory data associated with utilities in a combined cogeneration power plant.

\begin{tabular}{|c|c|c|c|c|}
\hline \multirow{2}{*}{ Environmental load } & \multirow{2}{*}{ Unit } & \multicolumn{3}{|c|}{ Year } \\
\hline & & 2013 & 2014 & 2015 \\
\hline \multicolumn{5}{|c|}{ Demineralized water production } \\
\hline \multicolumn{5}{|c|}{ INPUT } \\
\hline RO water & $\mathrm{L}$ & $1.00 \mathrm{E}+00$ & $1.00 \mathrm{E}+00$ & $1.00 \mathrm{E}+00$ \\
\hline $\begin{array}{c}\text { Hydrochloric acid } \\
(35 \%)\end{array}$ & $\mathrm{kg}$ & $1.69 \mathrm{E}-04$ & $1.11 \mathrm{E}-04$ & $1.15 \mathrm{E}-04$ \\
\hline $\begin{array}{l}\text { Sodium hydroxide } \\
(50 \%)\end{array}$ & $\mathrm{kg}$ & $1.38 \mathrm{E}-04$ & $9.46 \mathrm{E}-05$ & $9.47 \mathrm{E}-05$ \\
\hline Phosphonate & $\mathrm{kg}$ & $1.08 \mathrm{E}-05$ & $3.40 \mathrm{E}-06$ & $3.50 \mathrm{E}-06$ \\
\hline Citric acid & $\mathrm{kg}$ & $8.30 \mathrm{E}-06$ & $8.84 \mathrm{E}-06$ & $4.09 \mathrm{E}-06$ \\
\hline Sodium hypochlorite & $\mathrm{kg}$ & $1.20 \mathrm{E}-06$ & $3.15 \mathrm{E}-06$ & $4.39 \mathrm{E}-06$ \\
\hline Sodium metabisulphite & $\mathrm{kg}$ & $4.60 \mathrm{E}-06$ & - & - \\
\hline Biocide & $\mathrm{kg}$ & $4.20 \mathrm{E}-06$ & $1.10 \mathrm{E}-05$ & $1.15 \mathrm{E}-05$ \\
\hline \multicolumn{5}{|c|}{ OUTPUT } \\
\hline Demineralized water & $\mathrm{L}$ & $1.00 \mathrm{E}+00$ & $1.00 \mathrm{E}+00$ & $1.00 \mathrm{E}+00$ \\
\hline \multicolumn{5}{|c|}{ Cooling water production } \\
\hline \multicolumn{5}{|c|}{ INPUT } \\
\hline Raw water & $\mathrm{L}$ & $1.00 \mathrm{E}+00$ & $1.00 \mathrm{E}+00$ & $1.00 \mathrm{E}+00$ \\
\hline Sulphuric acid (50\%) & $\mathrm{kg}$ & $1.22 \mathrm{E}-04$ & $1.86 \mathrm{E}-04$ & $1.36 \mathrm{E}-04$ \\
\hline Sodium hypochlorite & $\mathrm{kg}$ & $1.02 \mathrm{E}-04$ & $1.17 \mathrm{E}-04$ & $1.06 \mathrm{E}-04$ \\
\hline Inhibitor AZ8101 & $\mathrm{kg}$ & $1.20 \mathrm{E}-07$ & $1.85 \mathrm{E}-06$ & $2.77 \mathrm{E}-06$ \\
\hline Spectrus NX1100 & $\mathrm{kg}$ & $1.78 \mathrm{E}-06$ & $2.90 \mathrm{E}-06$ & $4.56 \mathrm{E}-06$ \\
\hline Corrosion MS6209 & $\mathrm{kg}$ & $5.22 \mathrm{E}-06$ & $1.97 \mathrm{E}-06$ & $1.88 \mathrm{E}-06$ \\
\hline Scale GN7004 & $\mathrm{kg}$ & $8.15 \mathrm{E}-06$ & $1.09 \mathrm{E}-05$ & $8.00 \mathrm{E}-06$ \\
\hline \multicolumn{5}{|c|}{ OUTPUT } \\
\hline Cooling water & $\mathrm{L}$ & $1.00 \mathrm{E}+00$ & $1.00 \mathrm{E}+00$ & $1.00 \mathrm{E}+00$ \\
\hline \multicolumn{5}{|c|}{ Chiller water production } \\
\hline \multicolumn{5}{|c|}{ INPUT } \\
\hline Raw water & $\mathrm{L}$ & $1.00 \mathrm{E}+00$ & $1.00 \mathrm{E}+00$ & $1.00 \mathrm{E}+00$ \\
\hline Nitrite & $\mathrm{kg}$ & $7.72 \mathrm{E}-03$ & $7.72 \mathrm{E}-03$ & $7.72 \mathrm{E}-03$ \\
\hline \multicolumn{5}{|c|}{ OUTPUT } \\
\hline Chiller water & $\mathrm{L}$ & $1.00 \mathrm{E}+00$ & $1.00 \mathrm{E}+00$ & $1.00 \mathrm{E}+00$ \\
\hline
\end{tabular}


Table 5. Main input data and product.

\begin{tabular}{|c|c|c|c|c|}
\hline & \multirow{2}{*}{ Unit } & \multicolumn{3}{|c|}{ Year } \\
\hline & & 2013 & 2014 & 2015 \\
\hline \multicolumn{5}{|c|}{ INPUT } \\
\hline Natural gas & $\mathrm{kg}$ & $8.50 \mathrm{E}+07$ & $1.75 \mathrm{E}+08$ & $1.62 \mathrm{E}+08$ \\
\hline $\begin{array}{l}\text { Demineralized } \\
\text { water }\end{array}$ & $\mathrm{m}^{3}$ & $4.09 \mathrm{E}+04$ & $1.42 \mathrm{E}+05$ & $1.58 \mathrm{E}+05$ \\
\hline \multicolumn{5}{|c|}{ OUTPUT } \\
\hline Electricity & $\mathrm{kWh}$ & $3.86 \mathrm{E}+08$ & $7.97 \mathrm{E}+08$ & $7.95 \mathrm{E}+08$ \\
\hline Steam & ton & $2.57 \mathrm{E}+04$ & $9.43 \mathrm{E}+04$ & $9.73 E+04$ \\
\hline
\end{tabular}

assessed by using LCA of the operating cogeneration power plants and demonstrated by comparing with those caused by the gas turbine power plants for which efficiency was enhanced by cooling down the temperature of the air input before it went to the compressor using 2 methodologies: evaporative and fogging. The possible incremental efficiency rates were shifted one by one from $1 \%, 2 \%$, and $5 \%$ to $10 \%$. The data was derived from information in previous related studies to calculate the total amount of exploited materials and product yields based on the operational data in 2015 as the base case.

\section{Results and Discussion}

\section{Life Cycle Inventory Results}

The data used in this study were mainly primary data obtained from the actual processing involved. However, some secondary data, e.g., for chemical and natural gas production, was obtained from extensive generic LCA databases such as Eco-Invent or the Thailand Life Cycle Inventory Database. The data from each process was collected and computed into meaningful findings, as stated in the objective and system boundary setting. The product system was also developed to calculate the amount of input and output in terms of material and energy exploitation as well as waste emission. Such information was used to quantify environmental impact throughout the life cycle of the product. The main materials and product yields are described in Table 5 .

From Table 5, the least materials exploitation and least product yields were in 2013, which was the first year of operation. Thus, there were only 7 months left for collection of data. When computing the materials used and product yields per unit ratio, it was found that the amount of natural gas used from 2013 to 2015 was $2.09 \mathrm{E}-01 \mathrm{~kg} / \mathrm{kWh}, 2.01 \mathrm{E}-01 \mathrm{~kg} / \mathrm{kWh}$, and $1.86 \mathrm{E}-01 \mathrm{~kg} / \mathrm{kWh}$, respectively. For steam production, natural gas was required in 2013, 2014, and 2015 at $163.08 \mathrm{~kg} /$ ton steam, $156.56 \mathrm{~kg} /$ ton steam, and $144.90 \mathrm{~kg} / \mathrm{ton}$ steam, respectively, which was in a declining trend. Demineralised water usage in electricity generation between 2013 and 2015 was $0.10 \mathrm{~L} / \mathrm{kWh}, \quad 0.16 \mathrm{~L} / \mathrm{kWh}$, and $0.18 \mathrm{~L} / \mathrm{kWh}$, respectively, while demineralised water usage per steam was $78.52 \mathrm{~L} /$ ton steam, $127.10 \mathrm{~L} /$ ton steam, and $141.01 \mathrm{~L} /$ ton steam, respectively. The power plant efficiencies during the period between 2013 and 2015 were $48.2 \%, 48.8 \%$, and $48.8 \%$, respectively, which were close to that of NGCC power plants at $48.8 \%$ [39].

\section{Life Cycle Impact Assessment Results}

Life cycle impact assessment of the product was intended to evaluate the environmental impact of the product system based on material usage and waste emission, or the input and output obtained from the environmental inventory analysis. Besides, this study focused on a cogeneration power plant, which meant that steam generation had to be involved and assessed as well. The results were based on the same data as that of electricity generation, but were classified separately by allocation method, as in Table 2. Therefore, the results or environmental profiles were different each year, as seen in Tables 6 and 7.

The characterization results of electricity production are shown in Table 6. It was found that global warming potential in 2015 was $5.33 \mathrm{E}-01 \mathrm{~kg} \mathrm{CO}$ eq $/ \mathrm{kWh}$, which was the highest among the 3 years despite the least natural gas usage. Such potential came primarily from natural gas combustion during the production process (as in Fig. 2a). Transportation posted a minor contribution. After in-depth study, the global warming potential was incurred all 3 years, $93-95 \%$ of which was caused by the production process as a result of

Table 6. Environmental profile of electricity production by impact categories of interest (characterization results).

\begin{tabular}{|c|c|c|c|c|}
\hline \multirow{2}{*}{ Impact categories } & \multirow{2}{*}{ Unit } & 2013 & 2014 & 2015 \\
\cline { 3 - 5 } & & $4.90 \mathrm{E}-01$ & $4.64 \mathrm{E}-01$ & $5.33 \mathrm{E}-01$ \\
\hline Global warming & $\mathrm{kg} \mathrm{CO}_{2} \mathrm{eq} / \mathrm{kWh}$ & $7.99 \mathrm{E}-04$ & $7.36 \mathrm{E}-04$ & $6.07 \mathrm{E}-04$ \\
\hline Acidification & $\mathrm{kg} \mathrm{SO}_{2} \mathrm{eq} / \mathrm{kWh}$ & $3.38 \mathrm{E}-05$ & $3.72 \mathrm{E}-05$ & $3.48 \mathrm{E}-05$ \\
\hline Eutrophication & $\mathrm{kg} \mathrm{Peq} / \mathrm{kWh}$ & $8.60 \mathrm{E}-03$ & $8.16 \mathrm{E}-03$ & $7.94 \mathrm{E}-03$ \\
\hline Human toxicity & $\mathrm{kg} 1,4 \mathrm{DBeq} / \mathrm{kWh}$ & \\
\hline
\end{tabular}


Table 7. Environmental profile of steam production by impact categories of interest (characterization results).

\begin{tabular}{|c|c|c|c|c|}
\hline \multirow{2}{*}{ Impact categories } & \multirow{2}{*}{ Unit } & 2013 & 2014 & 2015 \\
\cline { 3 - 5 } & & $3.82 \mathrm{E}+02$ & $3.61 \mathrm{E}+02$ & $4.15 \mathrm{E}+02$ \\
\hline Global warming & $\mathrm{kg} \mathrm{CO}_{2}$ eq/ton steam & $1.88 \mathrm{E}+00$ & $5.26 \mathrm{E}-01$ & $5.78 \mathrm{E}-01$ \\
\hline Acidification & $\mathrm{kg} \mathrm{SO}_{2}$ eq/ ton steam & $2.64 \mathrm{E}-02$ & $2.89 \mathrm{E}-02$ & $2.71 \mathrm{E}-02$ \\
\hline Eutrophication & $\mathrm{kg} \mathrm{Peq} /$ ton steam & $6.70 \mathrm{E}+00$ & $6.35 \mathrm{E}+00$ & $6.18 \mathrm{E}+00$ \\
\hline Human toxicity & $\mathrm{kg} 1,4 \mathrm{DB} e q /$ ton steam & & \\
\hline
\end{tabular}

natural gas combustion. In 2013-2014, natural gas was imported from Myanmar connected to the western part of Thailand. However, the operational efficiency rate remained low since it began in 2013. In 2015 the source of natural gas was shifted to the Gulf of Thailand. Though natural gas usage in 2015 was similar to that in 2014 at $7.38 \mathrm{E}+00 \mathrm{MJ} / \mathrm{kWh}$, the GHG emission in 2015 was higher than the previous year, owning to the fact that natural gas components can vary in each different source, as shown in Table 8. Therefore, $\mathrm{CO}_{2}$ emissions per unit volume from the combustion of natural gas in Myanmar were lower than those in the Gulf of Thailand.

In terms of acidification, the potential was the highest in 2013 at $7.99 \mathrm{E}-04 \mathrm{~kg} \mathrm{SO}$ eq/ $\mathrm{kWh}$. The reason was in the way the natural gas was acquired (as in Fig. 2b). However, the main contributor when considering the whole production process was gas combustion, which released different levels of $\mathrm{SO}_{2}$ and $\mathrm{NO}_{\mathrm{x}}$ each year. Eutrophication potential in 2014 was the highest at $3.72 \mathrm{E}-05 \mathrm{~kg}$ Peq $/ \mathrm{kWh}$, owing to the production process (as in Figure 2c) because $\mathrm{NaOCl}$ $10 \%$ was used more than in the other years by $9-13 \%$ in cooling the same amount of water. Human toxicity was the highest in 2013 at $8.60 \mathrm{E}-03 \mathrm{~kg}$ 1,4DBeq $/ \mathrm{kWh}$ because of the water and $\mathrm{NaOCl} 10 \%$ used in the cooling process (as in Fig. 2d).

In the LCA impact of steam production, Table 7 shows the environmental impact potentials allocated to steam generation each year. Global warming potential was highest in 2015 at $4.15 \mathrm{E}+02 \mathrm{~kg} \mathrm{CO}$ eq/ton steam, $95 \%$ of which was caused by natural gas combustion (Fig. 3a). As mentioned earlier, the source of natural gas had been changed. In terms of acidification, it was highest in 2013 at $1.88 \mathrm{E}-00 \mathrm{~kg} \mathrm{SO}$ eq/ton steam, $76 \%$ of which was caused by natural gas combustion (Fig. 3b). When compared to 2014 and 2015, $\mathrm{NO}_{\mathrm{x}}$ released from combustion in 2013 was about 64.07 ppm, while that in 2014 and 2015 was about 7.35 ppm and 17.55 ppm, respectively. However, eutrophication was the highest in 2014 at 2.89E-02 kg Peq/ton steam, 58\% of which came from cooling water (Fig. 3c). Finally, human toxicity was highest in 2013 at $6.70 \mathrm{E}+00 \mathrm{~kg} 1,4 \mathrm{DBeq} /$ ton steam (Fig. 3d).

\section{Life Cycle Interpretation}

\section{Change of Natural Gas Origin}

The previous life cycle impact assessment considered information about natural gas acquisition in 2015, as obtained from the Thailand National Database [40]. Due to the lack of available data for natural gas production in Myanmar for 2013 and 2014, secondary data regarding natural gas production from the Gulf of Thailand in 2015 was taken into consideration and verified by sensitivity analysis, which is commonly used in LCA [41]. A sensitivity analysis was conducted to assess the influence of selecting important parameters in the system boundary [42]. How the secondary data varied when $10 \%$ increased and $10 \%$ decreased was taken into consideration. The results are shown in Fig. 4 for electricity generation and Fig. 5 for steam production. The change of source for natural gas did not significantly impact the assessment of global warming, eutrophication, and human toxicity potentials for both production processes with less than $1 \%$ variance. It affected acidification potential the most at $7.06-7.61 \%$ for electricity generation and 2.35$8.29 \%$ for steam production. However, eutrophication potential did not change at all because there were no associated assessment data available in the Thai National Database.

Table 8. Natural gas compositions between 2013 and 2015.

\begin{tabular}{|c|c|c|c|c|c|c|c|c|c|c|c|}
\hline \multirow{2}{*}{ Year } & \multicolumn{11}{|c|}{ Natural gas composition } \\
\hline & $\mathrm{CH}_{4}$ & $\mathrm{C}_{2} \mathrm{H}_{6}$ & $\mathrm{C}_{3} \mathrm{H}_{8}$ & $\mathrm{iC}_{4} \mathrm{H}_{10}$ & $\mathrm{nC}_{4} \mathrm{H}_{10}$ & $\mathrm{iC}_{5} \mathrm{H}_{12}$ & $\mathrm{nC}_{5} \mathrm{H}_{12}$ & $\mathrm{C}_{6} \mathrm{H}_{14}$ & $\mathrm{CO}_{2}$ & $\mathrm{~N}_{2}$ & Sum \\
\hline 2013 & 72.91 & 3.68 & 1.12 & 0.24 & 0.28 & 0.11 & 0.06 & 0.09 & 6.82 & 14.71 & 100.00 \\
\hline 2014 & 74.63 & 2.54 & 0.73 & 0.16 & 0.18 & 0.07 & 0.04 & 0.07 & 6.35 & 15.23 & 100.00 \\
\hline 2015 & 88.15 & 3.03 & 1.04 & 0.24 & 0.21 & 0.07 & 0.04 & 0.03 & 5.51 & 1.69 & 100.00 \\
\hline
\end{tabular}


a)

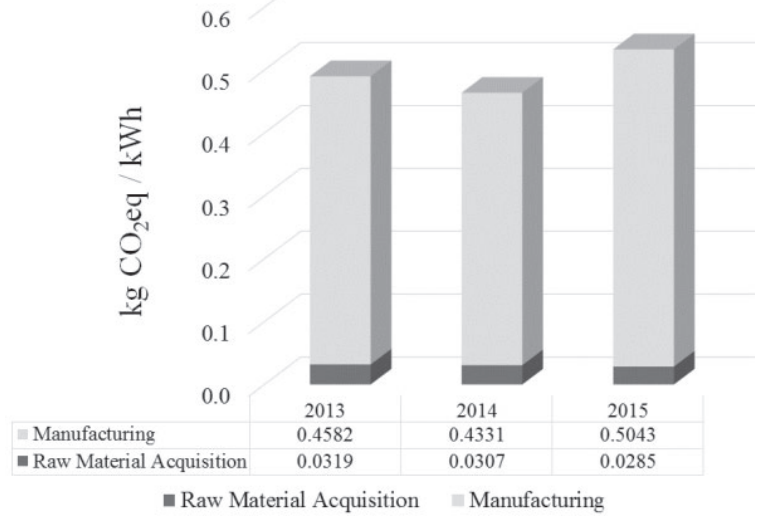

b)

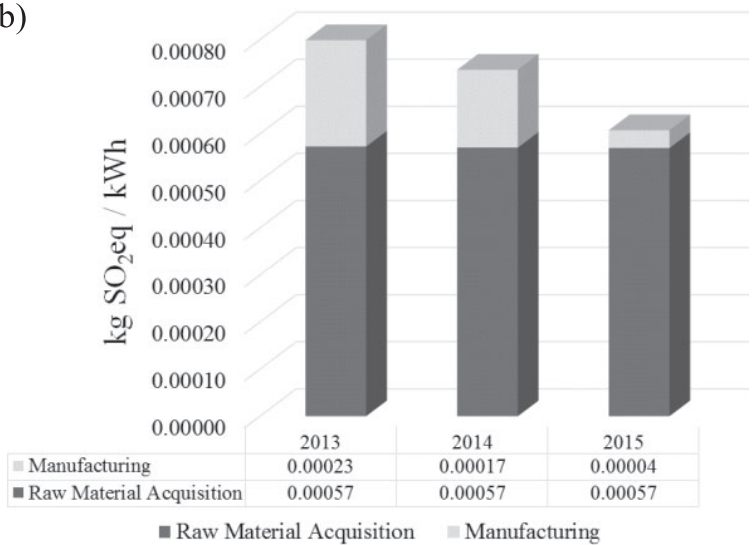

c)

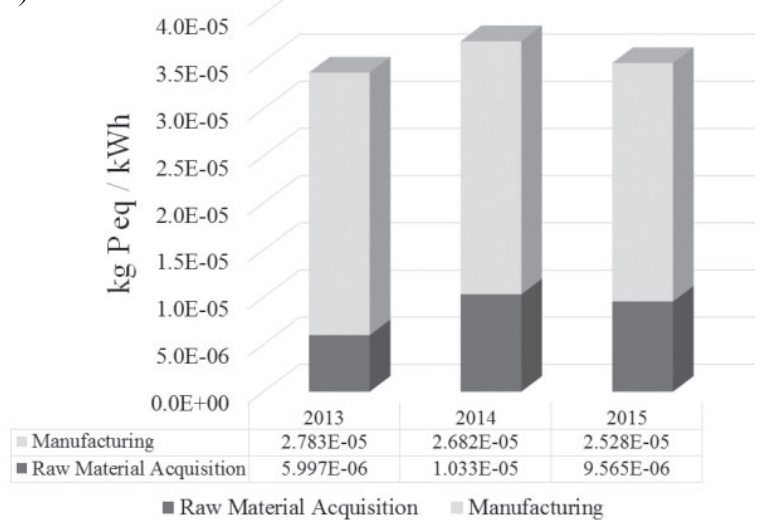

d)

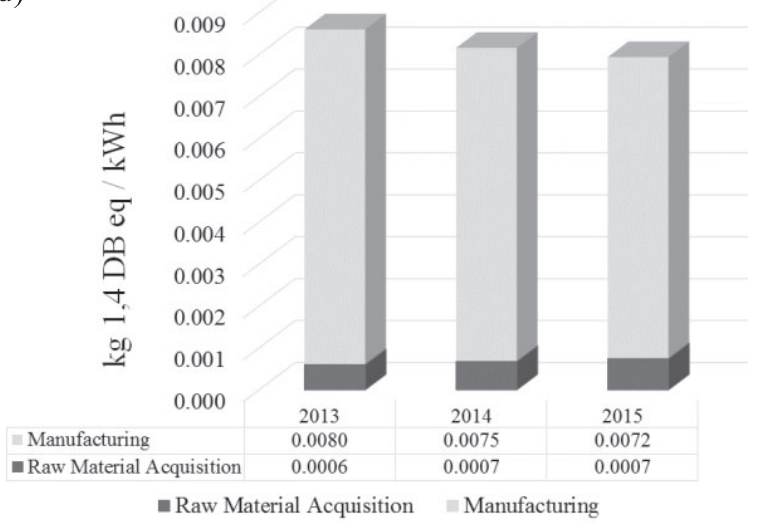

Fig. 2. Comparison of environmental impact in each life cycle stage of $1 \mathrm{kWh}$ : a) global warming potential, b) acidification potential, c) eutrophication potential, and d) human toxicity potential. a)

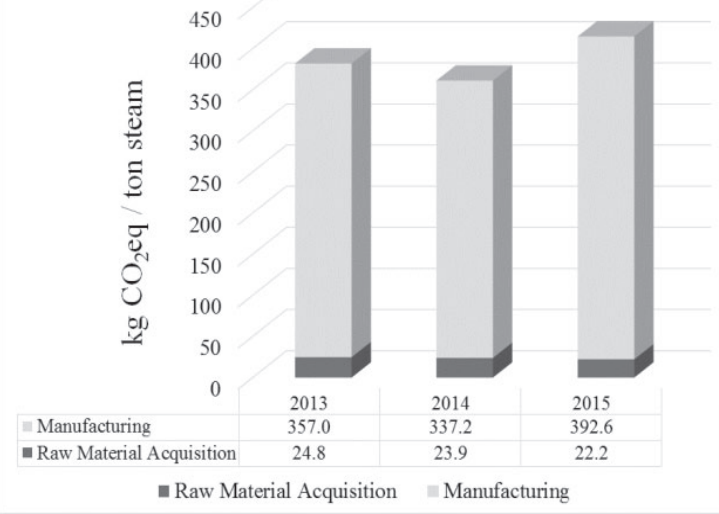

b)

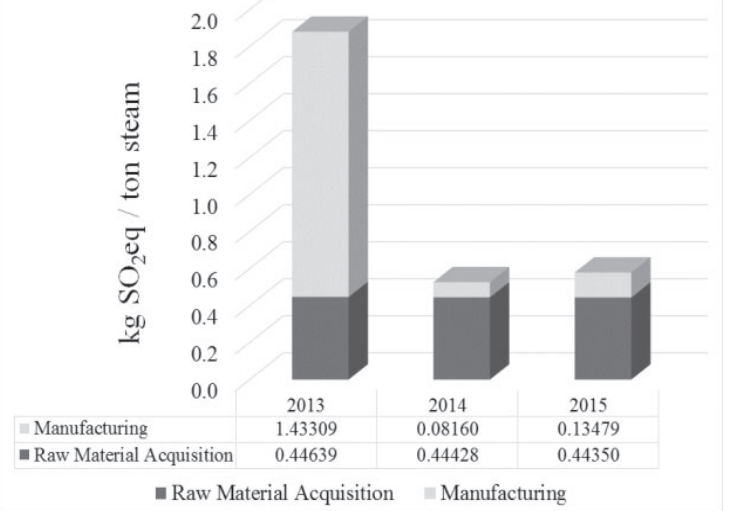

c)

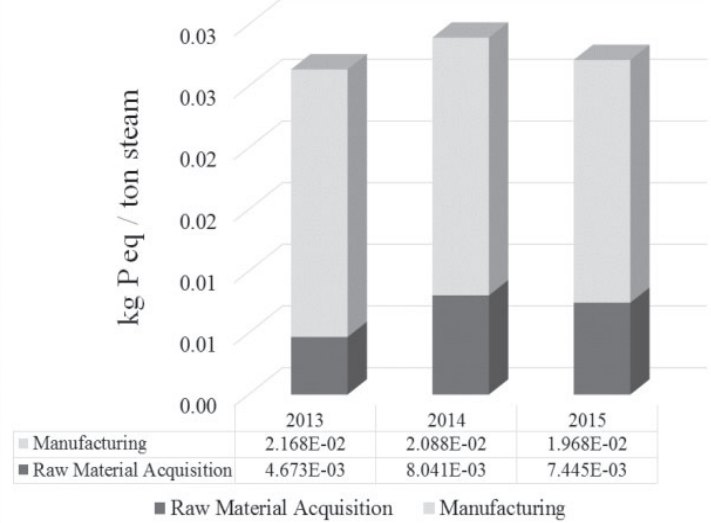

d)

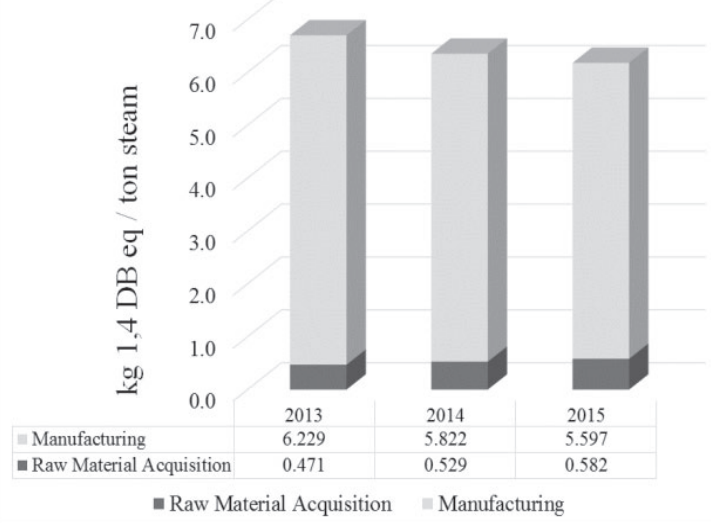

Fig. 3. Comparison of environmental impact in each life cycle stage of steam 1 ton: a) global warming potential, b) acidification potential, c) eutrophication potential, and d) human toxicity potential. 

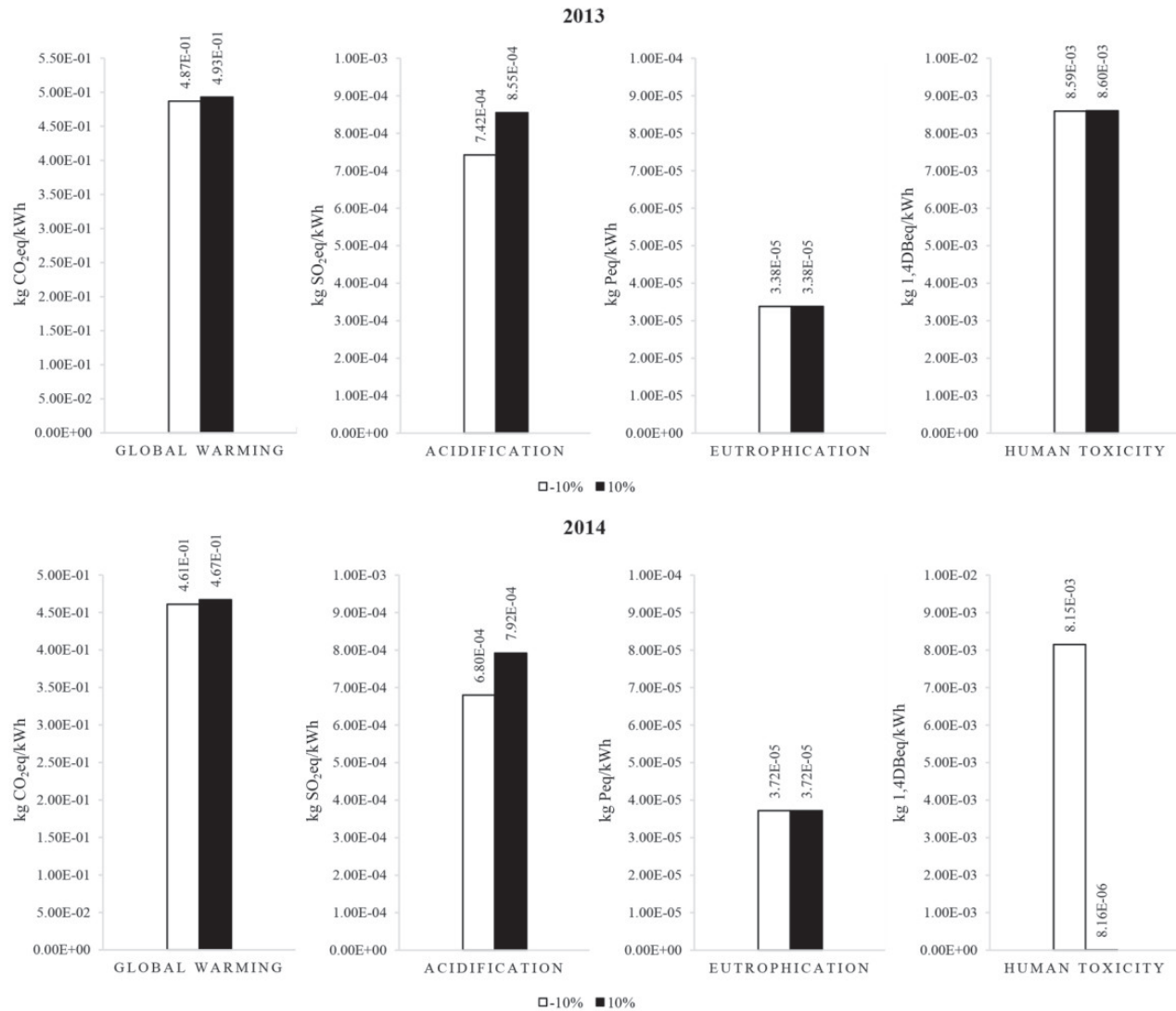

Fig. 4. Sensitivity analysis of environmental profile for electricity production.
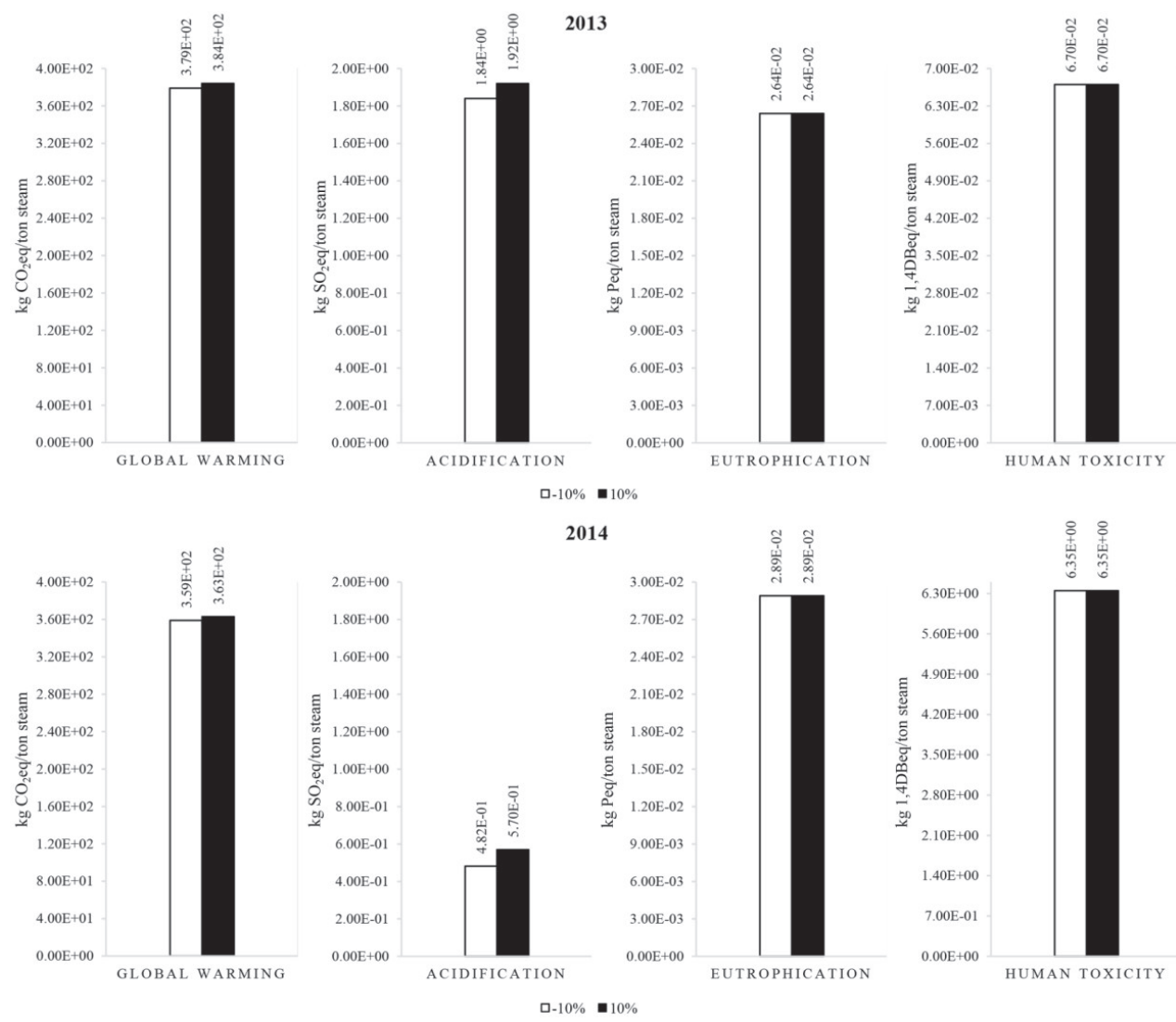

Fig. 5. Sensitivity analysis of environmental profile for steam production. 


\section{Efficiency Improvement of Combined Cycle Power Plants}

Several researchers have studied how to improve the efficiency of combined cycle power plants [7-8]. They found that ample methods were possible, including by cooling down the air temperature prior to being fed to the gas turbine or the compressor. However, this study focused on the latter, which involves cooling air before the compressor input by employing evaporative and fogging methods. The following are potential methods for application in this case study.

- Evaporative method is suitable for hot ambient air with low humidity. Evaporation forced by latent heat of the air causes the temperature to cool down as it reduces the level of heat exposure. Simultaneously, the latent heat of the air increases as water evaporates at an equal level to the heat exposure reduction. Therefore, it can be assumed that this process does not cause any change to the heat in the air and is classified as enthalpy $(\mathrm{h}=$ constant $)$ [7].

- Fogging method relies on a fogging system to reduce the temperature of the air. High-pressure steam is fogged into the air and causes evaporation as well as subsequent energy absorption from the air current, resulting in a lower temperature and higher humidity in the air. This process can be assumed to possess a similar mechanism to the evaporative method, though the fogging method can cause saturated air [7].

The evaporative method can increase efficiency by $2.64 \%$, while the fogging method can increase it by $5.73 \%$ [7] depending on the weather conditions in each location and the basic performance efficiency of the machinery in the power plants. When efficiency was increased by the possible mentioned rate, environmental impact caused by electricity and steam generation can vary, as shown in Figs 6-9.

The evaporative method was done by increasing the amount of demineralized water used in the production process to $5,460 \mathrm{~m}^{3} /$ year, thereby increasing efficiency by $2.64 \%$ [7]. Thus, $2,068 \mathrm{~m}^{3}$ more demineralized water is required per year to increase efficiency by 1\%. Figs 6 and 7 show the impact caused by efficiency improvement through the evaporative method compared to normal operation in 2015. It was found that global warming potential decreased by $0.94 \%$ when efficiency was increased by $1 \%$, while acidification potential was
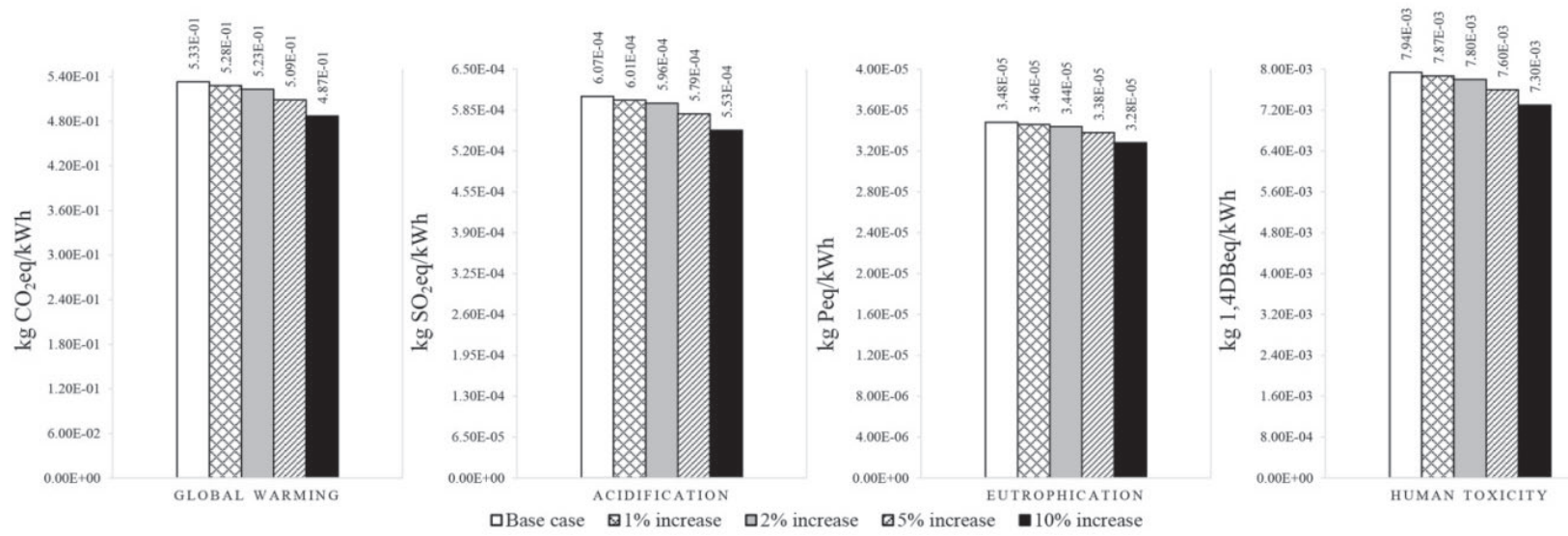

Fig. 6. Life cycle impact assessment of electricity production (evaporative method).
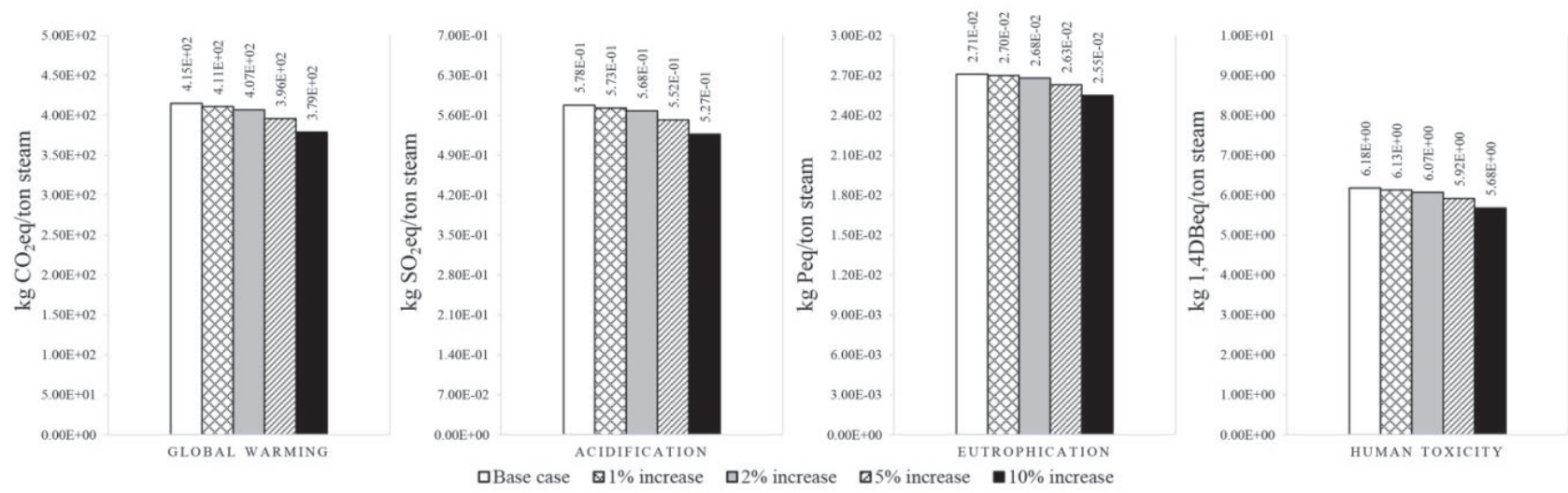

Fig. 7. Life cycle impact assessment of steam production (evaporative method). 
reduced by $0.97 \%$ per $1 \%$ of incremental efficiency. In terms of eutrophication, this potential decreased by $0.63 \%$ per $1 \%$ of incremental efficiency. Lastly, human toxicity decreased by $0.88 \%$ per $1 \%$ of incremental efficiency. For environmental impact on steam production, we found that all environmental impact decreased by less than $1 \%$ when efficiency increased by $1 \%$.

In terms of the fogging method, increasing efficiency by $5.73 \%$ requires demineralized water at $30,296.6 \mathrm{~m}^{3} /$ year [7]. In other words, demineralized water is additionally required for $5,286 \mathrm{~m}^{3} /$ year in order to increase efficiency by $1 \%$. According to Figs 8 and 9, efficiency enhancement causes a reduction in environmental impact. Global warming reduced by $0.99 \%$ per $1 \%$ of incremental efficiency, while acidification, eutrophication, and human toxicity decreased by $0.94 \%, 0.08 \%$, and $0.70 \%$ per $1 \%$ of incremental efficiency, respectively.

The fogging method was proven to reduce global warming potential more significantly than the other method. On the other hand, the evaporative method was more effective in terms of acidification, eutrophication, and human toxicity reduction. This can be explained by water demineralization being the main contributor to these 3 potentials and the evaporative method used less demineralized water. Nevertheless, it was found that both methods caused environmental impact to a similar extent when considered by functional unit. However, the fogging system gave a higher rate of return than the evaporative cooling system when considering the economic aspect [7].

\section{Environmental Impact Comparison to other Studies}

Literature reports several LCA of electricity production with various energy sources. In this study, however, the focus was on natural gas-based electricity generation. After comprehensive comparison, there was a wide range of results owing to factors such as impact assessment method, system boundary, or allocation method. Therefore, a comparison of only the results is probably not quite effective, but is acceptable. Turconi et al. [26] summarised that GHG emissions from combined cycle plants were in the range $610-850 \mathrm{~kg}$ $\mathrm{CO}_{2}$ eq/MWh, overall $\mathrm{NO}_{\mathrm{x}}$ emissions were in the range $0.2-1.3 \mathrm{~kg} \mathrm{NO} / \mathrm{MWh}$, and emissions of $\mathrm{SO}_{2}$ were in the range 0.01-0.32 $\mathrm{kg} \mathrm{SO}$ eq/MWh. Hondo (2005) reported $\mathrm{GHG}$ emissions of liquefied natural gas combined cycle (LNGCC) power generation in the value of $518.8 \mathrm{~g} \mathrm{CO}_{2} \mathrm{eq} / \mathrm{kWh}$ [43]. However, this result
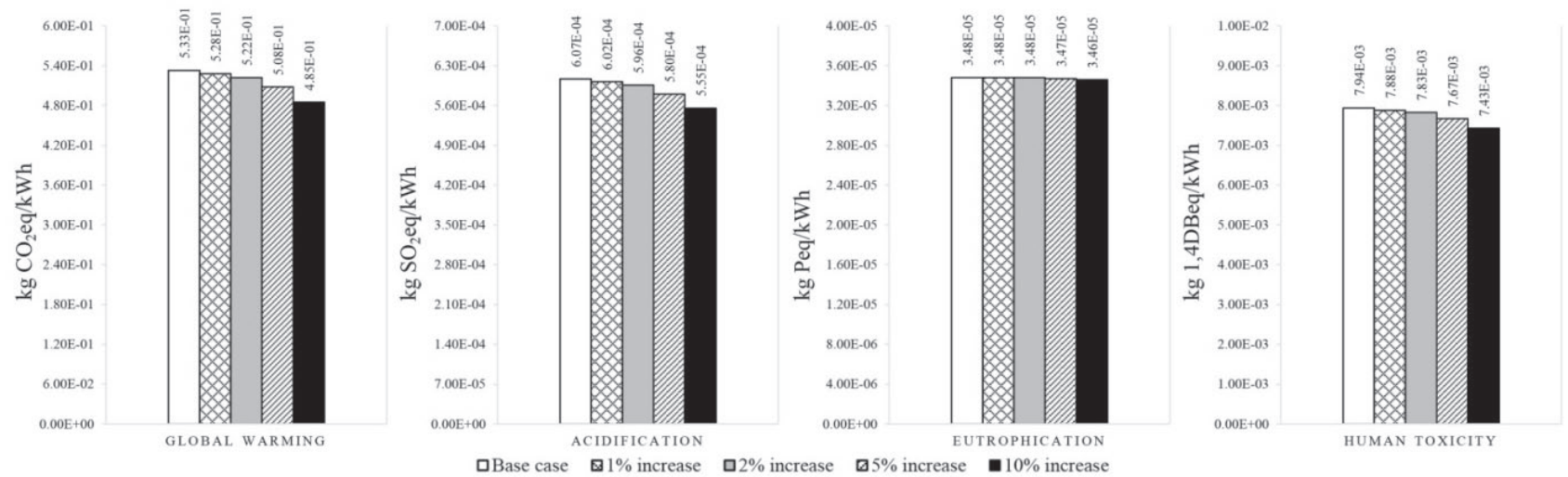

Fig. 8. Life cycle impact assessment of electricity production (fogging method).
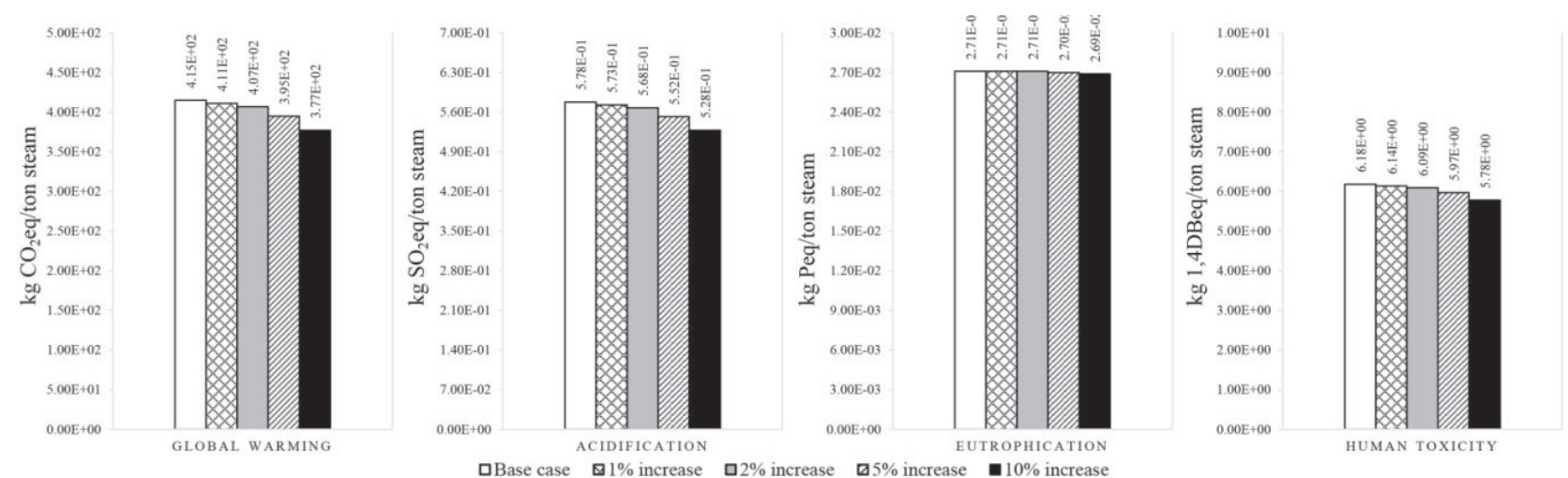

Fig. 9. Life cycle impact assessment of steam production (fogging method). 
included the construction phase, which was at $2.7 \mathrm{~g}$ $\mathrm{CO}_{2} \mathrm{eq} / \mathrm{kWh}$, while $\mathrm{GHG}$ emissions from single LNG power generation amounted to $607.6 \mathrm{~g} \mathrm{CO}$ eq $/ \mathrm{kWh}$. However, the study of Hondo [43] suggested that the amount of $\mathrm{CH}_{4}$ emissions was converted into $\mathrm{CO}_{2}$ equivalents using a global warming potential factor of 21 , whereas the value used in this study was 25 . Spath and Mann [39] conducted an LCA of a combined cycle power plant that used natural gas equal to 505 MW. They found that global warming potential was at $0.499 \mathrm{~kg} \mathrm{CO}$ eq $/ \mathrm{kWh}$. IPCC 1996 methodology was applied to this assessment. It can be perceived that global warming potentials from previous studies are similar to this one. However, there is one case that presented a much higher level than the average level of GHG emissions. Banar and Cokaygil [44] conducted an LCA of natural gas combined-cycle (NGCC) power plants and reverted global warming potential at $2.8 \mathrm{~kg} \quad \mathrm{CO}_{2} \mathrm{eq} / \mathrm{kWh}$, acidification at $0.36 \mathrm{~kg}$ $\mathrm{SO}_{2}$ eq $/ \mathrm{kWh}$, eutrophication at $0.09 \mathrm{~kg} \mathrm{Peq} / \mathrm{kWh}$, and human toxicity at $0.86 \mathrm{~kg} 1,4 \mathrm{DBeq} / \mathrm{kWh}$ by using a CML2 baseline 2000 assessment method.

\section{Conclusions}

Concerns about insufficient electricity generation and increasing pollution in the environment each year have influenced numerous researchers to produce interesting and significant studies on the environmental impact potentials, namely global warming, acidification, eutrophication, and human toxicity - all caused by cogeneration power plants by using LCA. The environmental impact potentials were compiled during the period between 2013 and 2015, since the operation started. It was found that both electricity and steam generation in 2015 contributed to the highest global warming potential due to the change of natural gas origin. The efficiency of electricity generation can be improved through both the evaporative and fogging methods. It was found that once efficiency was increased by $1 \%$ using the evaporative method, global warming potential decreased by $0.94 \%$, acidification decreased by approximately $0.97 \%$, eutrophication decreased by $0.63 \%$, and human toxicity declined by $0.88 \%$. However, the results suggested that global warming potential decreased by $0.99 \%$ when the fogging method was employed, while acidification, eutrophication, and human toxicity reduced by $0.94 \%, 0.08 \%$, and $0.70 \%$ per $1 \%$ of incremental efficiency, respectively. Moreover, the fogging method proved its ability to reduce global warming potential more significantly than the evaporative method, though it was lower in terms of acidification potential, eutrophication potential, and human toxicity. However, the environmental impact results per functional unit for both methods were still not significantly different.

\section{Acknowledgements}

We thank Ms. K Khumwong for her assistance in data collection.

\section{References}

1. IPCC. Climate change 2014: Mitigation of climate change. Cambridge University Press, Cambridge, United Kingdom and New York, USA, 2014.

2. UNITED NATIONS. Adoption of the Paris agreement. Available online: https://unfccc.int/resource/docs/2015/ cop21/eng/109r01.pdf., (accessed 02 July 2016), 2015.

3. MINSTRY OF ENERGY. Energy Policy and Planning Office, Thailand Power Development Plan: PDP2015, Thailand, 2015.

4. MINISTRY OF ENERGY. 20-Year Thailand Energy Efficiency Development Plan (2011-2030), Thailand, 2011.

5. MINISTRY OF ENERGY. Department of Alternative Energy Development and Efficiency, Alternative Energy Development Plan: AEDP2015, Thailand, 2015.

6. ALHAZMY M.M., NAJJAR Y.S.H. Augmentation of gas turbine performance using air coolers. Appl Therm Eng. 24, 415, 2004

7. KANKOMOL B. The study for air temperature reducing technology to improve the gas turbine performance: a case study at small power producer. Master Thesis, King Mongkut's University of Technology North Bangkok, Thailand, 2011 [In Thai].

8. HEJAZI M.A.S., MONTASER K. Design guide for cool thermal storage. Applied Thermal Engineer Journal. 29, 1830, 1993.

9. AL-IBRAHIM A.M., VARNHAM A. A review of inlet air-cooling technologies for enhancing the performance of combustion turbines in Saudi Arabia, Appl Therm Eng. 30, 14-15, 1879, 2010.

10. THEODOSIOU G., KORONEOS C., STYlOS N. Environmental impacts of the Greek electricity generation sector. Sustainable Energy Technologies and Assessments. 5, 19, 2014.

11. DZIKUC M., PIWOWAR A. Life cycle assessment as an Eco-management tool within the power industry. Pol J Environ Stud. 24 (6), 2381, 2015.

12. CHEVALIER C., MEUNIER F. Environmental assessment of biogas co- or tri-generation units by life cycle analysis methodology. Appl Therm Eng. 25 (17-18), 3025, 2005.

13. GONZALEZ A., SALA J.M., FLORRES I., LOPEZ L.M. Application of thermoeconomics to the allocation of environmental loads in the life cycle assessment of cogeneration plants. Energy. 28, 557, 2003.

14. MAHLIA T.M.I., CHAN P.L. Life cycle cost analysis of fuel cell based cogeneration system for residential application in Malaysia. Renew Sust Energ Rev. 15 (1), 416, 2011.

15. LI S., GAO L., JIN H. Life cycle energy use and GHG emission assessment of coal-based SNG and power cogeneration technology in China. Energ Convers Manage. 112, 91, 2016

16. GUERRA J.P.M., COLETA JR. J.R., ARRUDA L.C.M., SILVA G.A., KULAY L. Comparative analysis of electricity cogeneration scenarios in sugarcane production by LCA. Int J Life Cycle Assess. 19 (4), 814, 2014. 
17. RAMJEAWON T. Life cycle assessment of electricity generation from bagasse in Mauritius. J Clean Prod. 16, 1727, 2008.

18. GIL M.P., MOYA A.M.C., DOMINGUEZ E.R. Life cycle assessment of the cogeneration process in the Cuban sugar industry. J Clean Prod. 41, 222, 2013.

19. MASHOKO L., MBOHWA C., THOMAS V.M. Life cycle inventory of electricity cogeneration from bagasse in the South African sugar industry. J Clean Prod. 39, 42, 2013.

20. SILVA D.A.L., DELAI I., MONTES M.L.D., OMETTO A.R. Life cycle assessment of the sugarcane bagasse electricity generation in Brazil. Renew Sust Energ Rev. 32, 532, 2014.

21. ENERGY REGULATORY COMMISSION. Power Plant Type, Thailand. Available online: http://www.erc.or.th/ ERCSPP/MPagePowerPlantType.aspx, (accessed 12 September 2016) [In Thai].

22. ISO14040, Environmental management-Life cycle assessment-Principles and framework (ISO14040:2006), European Standard EN ISO14040, The International Organization for Standardization, Geneva, Switzerland, 2006.

23. ASDRUBALI F., BALDINELLI G., D'ALESSANDRO F., SCRUCCA F. Life cycle assessment of electricity production from renewable energies: Review and results harmonization. Renew Sust Energ Rev. 42, 1113, 2015.

24. BHANDARI R., TRUDEWIND C.A., ZAPP P. Life cycle assessment of hydrogen production via electrolysis-a review. J Clean Prod. 85, 151, 2014.

25. EVANGELISTI S., LETTIERI P., BORELLO D., CLIFT R. Life cycle assessment of energy from waste via anaerobic digestion: A UK case study. Waste Manage. 24 (1), 226, 2014.

26. TURCONI R., BOLDRIN A., ASTRUP T. Life cycle assessment (LCA) of electricity generation technologies: Overview, comparability and limitations. Renew Sust Energ Rev. 28, 555, 2013.

27. LENZEN M., TRELOAR G. Life-Cycle inventories toward upstream production layers: implications for life-cycle assessment. J Ind Ecol. 6 (3-4), 137, 2008

28. FINNVEDEN G., HAUSCHILD M.Z., EKVALL T., GUNIEE J., HEIJUNGS R., HELLWEG S., KOEHLER A., PENNINGTON D., SUH S. Recent developments in life cycle assessment. J Environ Manage. 91(1), 1, 2009.

29. ISO14044, Environmental management-Life cycle assessment-Requirements and guidelines (ISO14044:2006), European Standard EN ISO14044, The International Organization for Standardization, Geneva, Switzerland, 2006.

30. REBITZER G., EKVALL T., FRISHKNECHT R., HUNKELER D., NORRIS G., RYDBERG T., SCHIMIDT W.P., SUH S., WEIDEMA B.P., PENNINGTON D.W. Life cycle assessment: Part 1: Framework, goal and scope definition, inventory analysis, and applications. Environ Int. 30 (5), 701, 2004.
31. ATILGAN B., AZAPAGIC A. Assessing the environmental sustainability of electricity generation in Turkey on a life cycle basis. Energies. 9 (1), 31, 2016.

32. CLARENS F., ESPI J.J., RAFAEL G.M., ROVIRA M., VEGA L.F. Life cycle assessment of $\mathrm{CaO}$ looping versus amine-based absorption for capturing $\mathrm{CO}_{2}$ in a subcritical coal power plant. Int J Greenh Gas Control. 46, 18, 2016.

33. GARCIA-GUSANO D., IRIBARREN D., MARTINGAMBOA M., DUFOUR J., ESPEGREN K., LIND A. Integration of life-cycle indicators into energy optimization models: the case study of power generation in Norway. $\mathbf{J}$ Clean Prod. 112 (4), 2693, 2016.

34. BRIZMOHUN R., RAMJEAWON T., AZAPAGIC A. Life cycle assessment of electricity generation in Mauritius. J Clean Prod. 106, 565, 2015.

35. CORONA B., RUIZ D., SAN M.G. Life cycle assessment of a HYSOL concentrated solar power plant: analyzing the effect of geographic location. Energies. 9 (6), 413, 2016.

36. DZIKUC M., TOMASZEWSKI M. The effects of ecological investments in the power industry and their financial structure: a case study for Poland. J Clean Prod. 118, 48, 2016.

37. ECOINVENT CENTRE. Ecoinvent Database Ver.2.2. categories for process, Ecoinvent Centre, Swiss Centre for Life Cycle Inventories, Zurich, Switzerland, 2010.

38. IPCC. Climate Change 2007: the Physical Science Basis. Intergovernmental Panel on Climate Change, New York, USA, 2007.

39. SPATH P.L., MANN M.K. Life cycle assessment of a natural gas combined-cycle power generation system, National Renewable Energy Laboratory, Midwest Research Institute, Colorado, USA, 2000.

40. MTEC. Thai national life cycle inventory database, National Metal and Materials Technology Center, National Science and Technology Development Agency of Thailand, Pathumthani, Thailand, 2014.

41. FANTIN V., GIULIANO A., MANFREDI M., OTTAVIANO G., STEGANOVA M., MASONI P. Environmental assessment of electricity generation from an Italian anaerobic digestion plant. Biomass Bioenerg. 83, 422, 2015.

42. LIJO L., GONZALEZ-GARCIA S., BACENETTI J., FIALA M., FEIJOO G., LEMA J.M., MOREIRA M.T. Life cycle assessment of electricity production in Italy from anaerobic co-digestion of pig slurry and energy crops. Renew Energy. 68, 625, 2014.

43. HONDO H. Life cycle GHG emission analysis of power generation systems: Japanese case. Energy. 30 (11-12), 2042, 2005.

44. BANAR M., COKAYGIL Z. Life cycle assessment of electricity production from natural gas combined cycle. Chem Eng Trans. 21, 157, 2010. 
